\title{
Badania złącza spawanego rury tytanowej z płytą sitową wymiennika ciepła
}

\author{
The tests of the joint of welded titanium tube \\ with a tube sheet of a heat exchanger
}

\section{Streszczenie}

W artykule przedstawiono wyniki badań złączy uzyskanych w wyniku spawania rur z technicznego tytanu z płytą sitową wymiennika ciepła. Złącza wykonano metodą TIG stosując różne natężenie przepływu gazu osłonowego oraz energie liniowe spawania. Na podstawie przeprowadzonych badań stwierdzono, iż jakość osłony gazowej jeziorka ciekłego metalu ma kluczowe znaczenie dla uzyskania żądanych właściwości połączenia. Natlenienie metalu spoiny wiąże się z wystąpieniem przebarwień lica, które stanowią miarę właściwości mechanicznych złącza. Wraz ze zwiększaniem energii liniowej wzrasta obszar SWC oraz średnia wielkość ziarna w tej strefie.

Słowa kluczowe: tytan, spawanie TIG, ściana sitowa

\section{Abstract}

The article presents the results of tests of welded joints of the pipe with sieve plate heat exchanger. Joins are made GTAW with different variants of gas shielding and heat input welding. On the basis of non-destructive testing and destructive joints pure titanium was found that the quality of the cover gas liquid metal is crucial to achieve the desired properties. This oxidation of the weld metal is associated with the occurrence of discoloration faces of weld, which are a measure of the mechanical joint. With the increase of the heat input increases $\mathrm{HAZ}$ area and the average grain size in these zone.

Keywords: titanium, GTAW, tube sheet

\section{Wstęp}

Tytan i stopy tytanu znajdują zastosowanie wszędzie tam, gdzie od materiału konstrukcyjnego wymaga się szczególnie wysokiej odporności na korozję i wysokiej wytrzymałości właściwej. Temperatura pracy elementów z tytanu technicznego nie przekracza zazwyczaj $300-350^{\circ} \mathrm{C}$. W wielu przypadkach tytan jest niezastąpiony w budowie aparatury dla przemysłu chemicznego, farmaceutycznego i petrochemicznego. Duża odporność korozyjna przy występowaniu stosunkowo dużych strumieni cieplnych determinuje jego zastosowanie w budowie wymienników ciepła, pełniących różnorodne funkcje. Z uwagi na bardzo dużą odporność na korozję w wodzie morskiej jest wykorzystywany w przemyśle stoczniowym. Wymienione cechy oraz brak uaktywnienia tytanu w wyniku jego napromieniowywania powodują, iż jest materiałem przydatnym do budowy reaktorów jądrowych $[1 \div 3]$. W celu szerszego zastosowania tytanu do budowy konstrukcji inżynierskich, konieczne jest opracowanie technologii spawania, umożliwiających uzyskanie złączy o żądanych właściwościach.

\section{Badania własne}

Badane połączenia powstały na drodze rozwalcowania rury w otworze, które to połączenie ma za zadanie przenoszenie obciążeń działających wzdłuż osi rury. Połączenie spawane pełni rolę doszczelnienia złącza. Płyta sitowa jest bimetalem uzyskanym przez zgrzanie stali P256 i tytanu technicznego Grade 1 o grubości $6 \mathrm{~mm}$. Rura $31,75 \times 0,7$ ze szwem została wykonana z tytanu technicznego Grade 2. Spoinę narożną wykonano metodą TIG, w osłonie argonu (99,998\%Ar) bez użycia materiału dodatkowego (142), przy zastosowaniu głowicy do spawania orbitalnego Polysoude TS 34 S, wyposażonej w klosz osłony gazowej. Proces spawania był prowadzony w sposób automatyczny w pozycji PK.

Złącza wykonano różnicując natężenie przepływu gazu osłonowego, czas napełniania klosza osłony gazowej oraz energię liniową spawania. Badaniom poddano cztery złącza (oznaczone jako 1,16,20 i 21) różniące się ponadto stanem powierzchni przed spawaniem (tablica I).

\section{Badania wizualne}

O jakości połączenia spawanego tytanu świadczy wygląd spoiny. Powstające przebarwienia wskazują na natlenienie spoiny, a w miarę zwiększania się stopnia natlenienia zmianie ulega kolor przebarwienia. Występowanie w strefie wpływu ciepła badanych próbek przebarwień koloru słomkowego świadczy o niewielkim natlenieniu warstwy wierzchniej i jest

Inż. Marcin Szmul - Fabryka Aparatury i Urządzeń „FAMET” S.A.; dr Robert Bański; Dr inż. Anna Pocica - Politechnika Opolska.

Autor korespondencyjny/Corresponding author. marcin.szmul@wp.pl 
dopuszczalne. Przebarwienia obserwowane na licu spoiny i SWC złącza 16 (rys. 1), tj. jasnoniebieski kolor przebarwienia lica i powierzchni tytanu są niedopuszczalne i świadczą o znacznym natlenieniu spoiny, które wpływa negatywnie na jej właściwości wytrzymałościowe. Tytan ze względu na duże powinowactwo chemiczne do tlenu intensywnie nasyca się nim w wysokich temperaturach; szczególnie w stanie ciekłym. W wyniku przemiany perytektycznej powstaje faza charakteryzująca się dużą twardością i kruchością [4]. Natlenienie złącza 16 jest spowodowane niedostateczną osłoną gazową, co jest wynikiem zbyt krótkiego czasu napełniania komory osłonowej. Oprócz przebarwień przy ocenie wizualnej nie stwierdzono żadnych innych niezgodności wymienianych w PN-EN 15614-8. Również badania penetracyjne i radiograficzne nie wykazały obecności niezgodności spawalniczych.

Tablica I. Parametry procesu spawania

Table I. Welding process parameters

\begin{tabular}{|c|c|c|c|c|c|c|}
\hline $\begin{array}{c}\text { Nr } \\
\text { złącza }\end{array}$ & $\begin{array}{c}\text { Powierzchnia } \\
\text { tytanu } \\
\text { oczyszczona }\end{array}$ & $\begin{array}{c}\text { T10 } \\
\text { [s] }\end{array}$ & $\begin{array}{c}\text { U } \\
\text { [V] }\end{array}$ & $\begin{array}{c}\text { I } \\
\text { [ A ] }\end{array}$ & $\begin{array}{c}\text { V Ar } \\
\text { [ I min ] }\end{array}$ & $\begin{array}{c}\text { Energia } \\
\text { liniowa } \\
\text { spawania } \\
\text { [kJ/cm] }\end{array}$ \\
\hline $\mathbf{1}$ & nie & 12 & 7,3 & 49 & 30 & 0,644 \\
\hline $\mathbf{1 6}$ & tak & 2 & 7,9 & 64 & 4 & 0,910 \\
\hline $\mathbf{2 0}$ & tak & 12 & 7,3 & 49 & 30 & 0,644 \\
\hline $\mathbf{2 1}$ & tak & 12 & 7,3 & 49 & 5 & 0,644 \\
\hline $\begin{array}{l}\text { T10 - czas wypływu gazu osłonowego przed zajarzeniem łuku } \\
\text { I - natężenie prądu spawania } \\
\text { U - napięcie łuku }\end{array}$
\end{tabular}

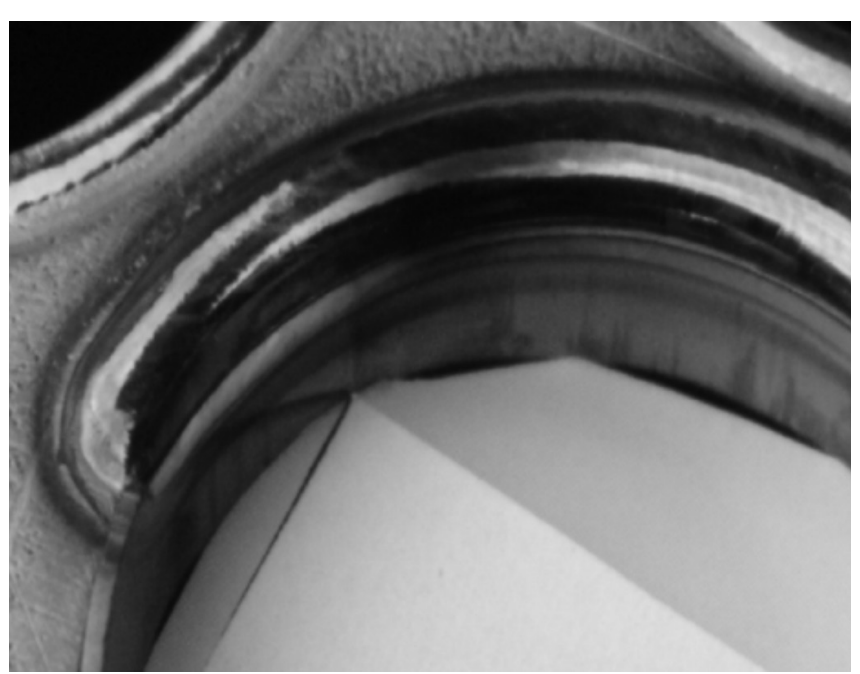

Rys. 1. Przebarwienia złącza spawanego nr 16

Fig. 1. Discolorations of the face of weld the welded joint number 16

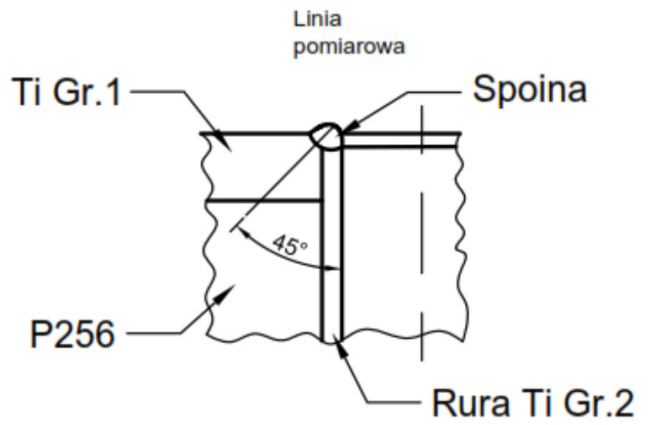

Rys. 2. Schemat prowadzenia linii pomiarowej

Fig. 2. Diagram of the position of the measurement line

\section{Badania mikrotwardości}

Pomiary mikrotwardości przeprowadzono na twardościomierzu LECO MHT SERIES 200 metodą Vickersa, stosując obciążenie $0,1 \mathrm{~kg}$. Odległości pomiędzy odciskami wyniosły $0,3 \mathrm{~mm}$. Schemat prowadzenia linii pomiarowej przedstawiono na rysunku 2. Badaniom poddano próbki pobrane ze złącza 1 (próbka 4.1), ze złącza 16 (próbka 5), ze złącza 21 (próbka 2.8) i ze złącza 20 (próbka 2.6).

Zbiorcze wyniki pomiarów przedstawiono na rysunku 3. Można zauważyć bardzo istotny wzrost twardości spoiny (do $380 H V 0,1$ ) próbki 5, pobranej ze złącza 16, które uległo znacznemu natlenieniu.

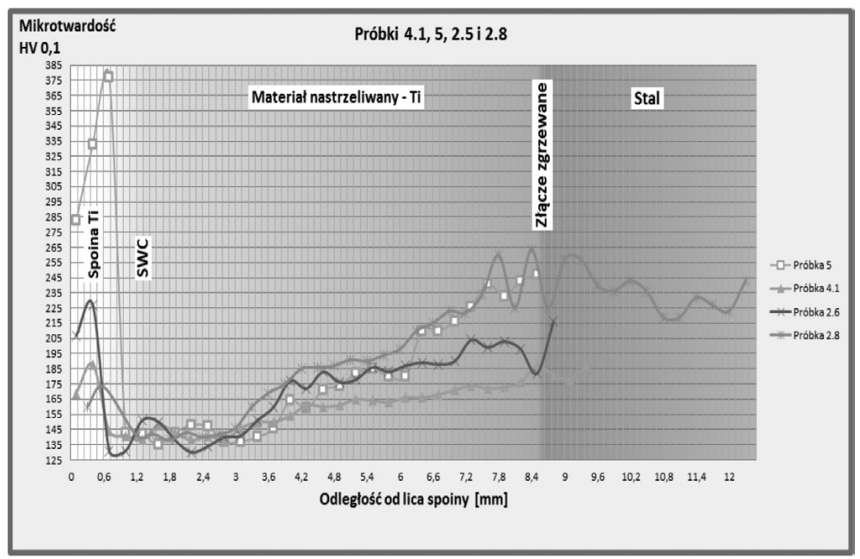

Rys. 3. Porównanie rozkładu mikrotwardości dla poszczególnych próbek złączy spawanych

Fig. 3. Hardness distribution in welded joints

Twardość strefy wpływu ciepła jest mniejsza niż materiału rodzimego (nastrzeliwanego). Następuje w tym obszarze intensywny rozrost ziarn oraz zanik wpływu umocnienia zgniotowego, wywołanego przebiegiem procesów zgrzewania wybuchowego, walcowania i obróbki cieplnej. Mikrotwardość materiału rodzimego rośnie w miarę zbliżania się do linii złącza zgrzewanego. W obrębie linii złącza zgrzewanego występuje charakterystyczny rozkład twardości połączenia tytan+stal. Umocnienie tego obszaru jest wynikiem silnych odkształceń powstałych podczas zgrzewania wybuchowego.

\section{Badania metalograficzne makroskopowe}

Badania zostały przeprowadzone zgodnie z EN 1321. Próbki poddano trawieniu 20\% roztworem wodnym kwasu fluorowodorowego. Według PN-EN ISO 15614-8 w prawidłowo wykonanym złączu spoina musi mieć odpowiednią grubość. Wyznacza ją promień największego okręgu wpisanego w spoinę, którego środek znajduje się w najniższym punkcie grani spoiny. Grubość spoiny powinna być większa, bądź równa 0,9 grubości ścianki rury. Zaobserwowaną makrostrukturę przedstawiono na rysunku 4. Po lewej stronie rysunku znajduje złącze nr 16, a po prawej złącze odpowiadające parametrami złączu nr 21. Złącza 1 i 20 zostały wykonane z taką samą energią liniową jak złącze 21, więc ich makrostruktura jest podobna.

Makrostrukturę złączy charakteryzuje duże zróżnicowanie pod względem wielkości ziarn w poszczególnych obszarach. Materiał rodzimy rury ma strukturę drobnoziarnistą, natomiast w materiale rodzimym warstwy tytanu płyty sitowej obserwuje się nieco większe ziarna. Ziarna rozrastają się od granicy SWC w kierunku spoiny i w spoinie występują ziarna o największych rozmiarach. Złącze nr 16 wyróżnia się większą szerokością SWC niż złącze 21. Jest to spowodowane 
większą energią liniową spawania, która wynosiła 0,91kJ/cm, podczas gdy dla złącza nr 21 wynosiła 0,644 kJ/cm. Większa ilość doprowadzonego ciepła spowodowała zwiększoną powierzchnię przekroju poprzecznego spoiny i SWC oraz zwiększenie rozmiarów ziarn. Makrostruktura złącza nr 16 ukazuje wyraźną granicę pomiędzy spoiną a SWC. Wynika ona $z$ różnic $w$ składzie fazowym spoiny i SWC, gdyż spoina została nasycona tlenem podczas procesu spawania. Stwierdzono również, że jedynie złącze nr 16 spełnienia wymagania normy w zakresie grubości spoiny.

\section{Analiza wyników badań}

Wyniki przeprowadzonych badań pozwalają stwierdzić, iż zanieczyszczenie powierzchni tytanu w postaci zwartej warstwy tlenków koloru szarego nie wpłynęło na wystąpienie przebarwień lica spoiny oraz na pogorszenie właściwości plastycznych połączenia. Również zmniejszenie natężenia przepływu gazu osłonowego z $30 \mathrm{l} / \mathrm{min}$ do $5 \mathrm{l} / \mathrm{min}$, przy zachowaniu czasu napełniania komory osłonowej przed zajarzeniem łuku wynoszącym 12s, nie wpłynęło negatywnie na jakość osłony gazowej. Jedynie zmniejszenie czasu napełniania argonem komory osłonowej do $2 s$ przy natężeniu przepływu wynoszącym 4 l/min spowodowało wystąpie- nie natlenienia spoiny. Było ono spowodowane niecałkowitym wypełnieniem gazem osłonowym komory w momencie rozpoczęcia jarzenia łuku i dalszego spawania. Świadczy o tym zmieniający się kolor przebarwienia lica w miarę zmniejszania udziału powietrza w atmosferze ochronnej.

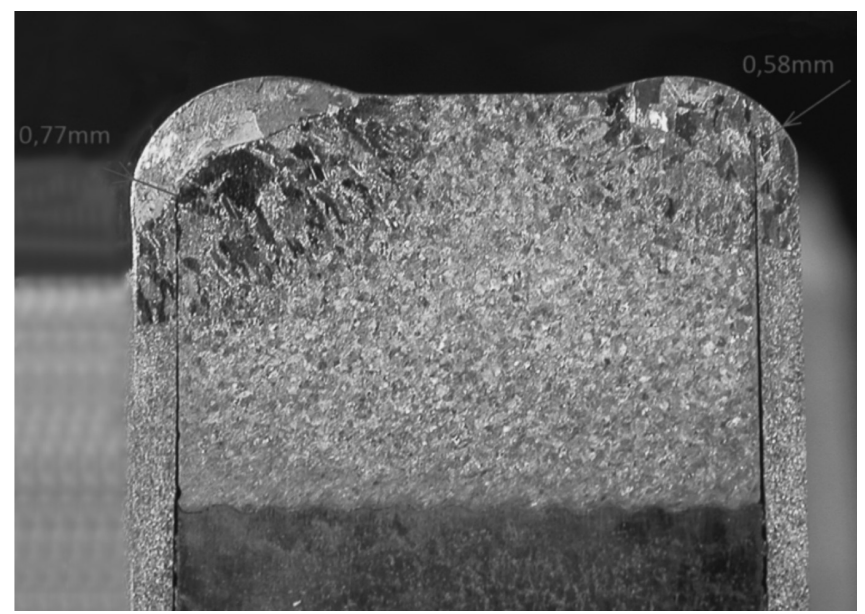

Rys. 4. Makrostruktura złącza 16 (po lewej) i złącza 21 (po prawej) Fig. 4. Macrostructure of welded joint numer 16 (on the left) and 21 (on the right)

\section{Wnioski}

- Właściwa osłona gazowa ma decydujący wpływ na uzyskane właściwości połączenia spawanego i jego strukturę.

- Kolor lica spoiny świadczy o skuteczności zastosowanej osłony gazowej. Potwierdzają to wykonane badania mikrotwardości oraz badania metalograficzne makroskopowe.

- W wyniku cyklu cieplnego procesu spawania następuje znaczny rozrost ziarn w spoinie i w SWC w stosunku do materiałów rodzimych rury i warstwy tytanowej plateru. Rozrost ten i zasięg SWC są zależne od wartości energii liniowej spawania.

\section{Literatura}

[1] BYLICA A., SIENIAWSKI J.: Tytan i jego stopy, PWN, Warszawa 1985, ISBN 83-01-05888-9.

[2] CISZEWSKI A., RADOMSKI T.: Obróbka oraz łączenie tytanu i jego stopów, WNT, Warszawa 1968.

[3] FILIPCZAK G., WITCZAK S.: Konstrukcja aparatury procesowej, Wyższa szkoła inżynierska w Opolu, Skrypt uczelniany nr 175, Opole 1995, ISSN 0860-9004
[4] DANIELSON P., WILSON R., ALMAN D.: Microstructure of titanium welds, Structure: Struers e journal of materialography 3/2004, U. S. Departament of energy, Albany research center, Albany. 